DOI: https://doi.org/10.24127/ajpm.v10i1.3361

\title{
HUBUNGAN KETERAMPILAN PROSES BERPIKIR MATEMATIS DENGAN HASIL BELAJAR MAHASISWA
}

\author{
Himmatul Ulya ${ }^{1 *}$, Ratri Rahayu ${ }^{2}$ \\ ${ }^{1 *, 2}$ Universitas Muria Kudus, Kudus, Indonesia \\ *Corresponding author. Gondangmanis, 59327, Kudus, Indonesia. \\ E-mail: $\quad$ himmatul.ulya@umk.ac.id ${ }^{1 *}$ \\ ratri.rahayu@umk.ac.id $^{2)}$
}

Received 07 December 2020; Received in revised form 09 March 2021; Accepted 31 March 2021

\begin{abstract}
Abstrak
Penelitian ini bertujuan untuk menguji hubungan antara keterampilan proses berpikir matematis mahasiswa dengan hasil belajar mahasiswa dan mendeskripsikan keterampilan proses berpikir matematis mahasiswa program studi Pendidikan Matematika semester VI dalam mata kuliah Analisis Kompleks. Subjek dalam penelitian adalah mahasiswa semester VI Program Studi Pendidikan Matematika Universitas Muria Kudus yang berjumlah 27 mahasiswa. Teknik pengumpulan data yang digunakan dalam penelitian ini melalui teknik tes. Teknik tes digunakan untuk mendapatkan hasil belajar mahasiswa aspek kognitif dan keterampilan proses berpikir matematis mahasiswa. Dalam penelitian ini menggunakan teknik analisis data yang meliputi analisis inferensial untuk menguji korelasi antarvariabel dan analisis deskriptif kuantitatif. Hasil penelitian ini menunjukkan bahwa terdapat hubungan antara keterampilan proses berpikir matematis mahasiswa dengan hasil belajar mahasiswa. Sebagian besar keterampilan proses berpikir matematis mahasiswa hanya mencapai predikat B yaitu sebesar $48,15 \%$ mahasiswa, rata-rata keterampilan proses berpikir matematis mahasiswa adalah 62,96 dan secara klasikal tergolong pada predikat BC, serta berdasarkan indikator, keterampilan proses berpikir matematis mahasiswa belum optimal karena hanya mencapai rata-rata $57,87 \%$.
\end{abstract}

Kata kunci: Hasil belajar; keterampilan proses berpikir matematis; Pendidikan Matematika Universitas Muria Kudus.

\begin{abstract}
This study aims to examine the relationship between students' mathematical thinking process skills and student learning outcomes and to describe the mathematical thinking process skills of students of the 6th semester Mathematics Education study program in the Complex Analysis subject. Subjects in the study were students of sixth semester Mathematics Education Universitas Muria Kudus totaling 27students. The data collection technique used in this study was through test techniques. The test technique is used to obtain student learning outcomes in cognitive aspects and students' mathematical thinking process skills. In this study, using data analysis techniques that include inferential analysis to test the correlation between variables and quantitative descriptive analysis. The results of this study indicate that there is a relationship between students' mathematical thinking process skills and student learning outcomes. Most of the students' mathematical thinking process skills only achieved predicate B, namely $48.15 \%$ of students, the average of students' mathematical thinking process skills was 62.96 and classically belonged to the BC predicate, and based on indicators, students' mathematical thinking process skills were not optimal. because it only reached an average of $57.87 \%$.
\end{abstract}

Keywords: Learning outcomes; mathematical thinking process skills; Mathematics Education Universitas Muria Kudus

This is an open access article under the Creative Commons Attribution 4.0 International License 
DOI: https://doi.org/10.24127/ajpm.v10i1.3361

\section{PENDAHULUAN}

Keterampilan (skills) dalam matematika adalah kemampuan untuk memberikan jawaban yang tepat dan cepat. Keterampilan dalam matematika dapat diukur melalui proses penilaian. Di dalam abad 21 ini, asesmen yang dilakukan dalam pembelajaran diharapkan dapat membangun kemampuan berpikir kritis, kolaborasi, kreativitas, dan komunikasi mahasiswa. Asesmen abad 21 tersebut telah termuat di dalam keterampilan proses berpikir matematis. Keterampilan proses berpikir matematis adalah keterampilan dalam menentukan pola dan menarik kesimpulan, mengkomunikasikan masalah ke dalam ide matematika, serta melakukan perhitungan matematika (Aminah \& Firmasari, 2017; Sumarmo, 2013).

Keterampilan proses berpikir matematis mahasiswa dinilai berdasarkan indikator (1) menentukan pola dan menarik kesimpulan, (2) mengkomunikasikan masalah ke dalam ide matematika, dan (3) melakukan perhitungan matematika (Aminah \& Firmasari, 2017).

Untuk mempelajari matematika, mahasiswa perlu memiliki keterampilan proses berpikir matematis. Namun, keterampilan proses berpikir matematis juga perlu didukung dengan kemampuan eksplorasi konsep-konsep matematis. Faktanya kemampuan pemahaman konsep peserta didik di Indonesia masih rendah (Andriani et al., 2016). Rendahnya kemampuan mengeksplorasi konsep matematika berakibat terhadap rendahnya keterampilan proses berpikir matematis mahasiswa. Hal ini menjadikan keterampilan proses berpikir matematis mahasiswa tidak berkembang dengan baik (Dewi, 2017). Selain itu, dimungkinkan terjadi dampak lain yaitu hasil belajar mahasiswa rendah. Namun, belum ada bukti penelitian yang membuktikan hal tersebut, sehingga perlu dilakukan penelusuran mengenai hubungan antara keterampilan proses berpikir matematis dengan hasil belajar matematis peserta didik.

Berdasarkan hasil wawancara diperoleh informasi bahwa selama ini pengukuran keterampilan proses berpikir matematis mahasiswa program studi Pendidikan Matematika belum pernah dilakukan. Penilaian yang dilakukan selama ini hanya sebatas mengukur kemampuan yang mengutamakan pemahaman konsep. Penyelesaian dari masalah-masalah pemahaman konsep hanya sebatas pengerjaan secara mekanik (Rahayu et al., 2018). Hal ini membuktikan bahwa keterampilan proses berpikir matematis belum menjadi perhatian oleh dosendosen di program studi Pendidikan Matematika. Berdasarkan hasil observasi yang dilakukan ketika pembelajaran, diperoleh informasi bahwa mahasiswa belum terampil dalam menentukan pola pemecahan masalah dan kesulitan untuk mengkomunikasikan masalah ke dalam ide matematika. Hal ini disebabkan karena mahasiswa belum memahami permasalahan yang sesungguhnya sehingga mahasiswa menemui kendala dalam menghubungkan dan mengeksplorasi antarkonsep yang akan digunakan. Berdasarkan hal tersebut, maka hasil belajar mahasiswa juga belum optimum. Keterampilan proses berpikir matematis dapat diukur selama pembelajaran. Pembelajaran yang dilakukan harus melibatkan mahasiswa agar aktif di dalam pembelajaran, sehingga keterampilan proses berpikir matematisnya dapat diukur. Indikator yang digunakan dalam mengukur keterampilan proses berpikir matematis meliputi mengamati, mengklasifikasi, 
menginterpretasi, memprediksi, menerapkan, dan mengkomunikasikan (Widyaningtyas, 2010). Melalui penilaian keterampilan proses berpikir matematis, mahasiswa tidak hanya diukur dari kemampuan kognitifnya saja melainkan diukur pula proses dalam pemecahan masalahnya (Aminah \& Firmasari, 2017). Penekanan pada penilaian proses berpikir matematis dapat memberikan manfaat bagi peserta didik yang kemampuan kognitifnya lebih rendah (Salmi et al., 2015).

Berdasarkan permasalahan yang ada, maka perlu ditelusuri mengenai hubungan keterampilan proses berpikir matematis mahasiswa dengan hasil belajar mahasiswa. Selanjutnya apabila keterampilan proses berpikir matematis berpengaruh terhadap hasil belajar, maka perlu dilakukan pendeskripsian lebih jelas tentang keterampilan proses berpikir matematis mahasiswa program studi Pendidikan Matematika. Selain itu. Penelusuran terhadap keterampilan proses berpikir matematis mahasiswa merupakan salah satu usaha yang dapat dilakukan dosen untuk mengatasi rendahnya hasil belajar mahasiswa. Setelah mengetahui hambatan dalam proses berpikir matematis yang dilakukan mahasiswa dalam menyelesaikan masalah matematika, dosen dapat membantu untuk mengatasi kendala tersebut. Langkah ini dapat dilakukan dosen untuk mengembangkan keterampilan proses berpikir matematis mahasiswa sehingga akan dapat berdampak pada hasil belajar mahasiswa yang semakin lebih baik.

Tujuan penelitian ini yaitu: (1) menguji hubungan antara keterampilan proses berpikir matematis mahasiswa dengan hasil belajar mahasiswa, dan (2) mendeskripsikan keterampilan proses berpikir matematis mahasiswa program studi Pendidikan Matematika semester
VI dalam mata kuliah Analisis Kompleks.

\section{METODE PENELITIAN}

Jenis penelitian yang digunakan dalam penelitian ini adalah penelitian kuantitatif. Di dalam penelitian ini menggunakan pendekatan korelasional dan deskripsi kuantitatif. Tahapan penelitian ini yaitu mahasiswa diberikan tes untuk mengukur hasil belajar mahasiswa aspek kognitif dan keterampilan proses berpikir matematis mahasiswa. Selanjutnya data dianalisis untuk: (1) menguji hubungan antara keterampilan proses berpikir matematis mahasiswa dengan hasil belajar mahasiswa dan (2) mendeskripsikan keterampilan proses berpikir matematis mahasiswa. Keterampilan proses berpikir matematis mahasiswa dinilai berdasarkan indikator (1) menentukan pola dan menarik kesimpulan, (2) mengkomunikasikan masalah ke dalam ide matematika, dan (3) melakukan perhitungan matematika (Aminah \& Firmasari, 2017).

Populasi yang digunakan adalah semua mahasiswa program studi Pendidikan Matematika tahun akademik 2019/2020 semester VI. Sampel jenuh digunakan dalam pengambilan sampel karena seluruh anggota populasi digunakan sebagai sampel. Sampel penelitian ini yaitu mahasiswa semester VI berjumlah 27 mahasiswa. Variabel bebas (X) dalam penelitian ini adalah keterampilan proses berpikir matematis, sedangkan variabel terikat (Y) yang digunakan yaitu hasil belajar mahasiswa aspek kognitif. Desain pola hubungan dari kedua variabel dapat digambarkan pada Gambar 1. Teknik pengumpulan data dalam penelitian ini melalui teknik tes. Teknik tes digunakan untuk mendapatkan hasil belajar mahasiswa aspek kognitif dan keterampilan proses 
DOI: https://doi.org/10.24127/ajpm.v10i1.3361

berpikir matematis mahasiswa. Instrumen yang digunakan adalah instrumen tes.

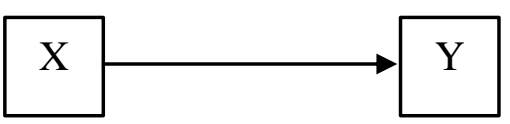

Gambar 1. Pola hubungan antara keterampilan proses berpikir matematis (X) dan hasil belajar mahasiswa aspek kognitif (Y)

Analisis data dalam penelitian ini menggunakan analisis inferensial dan analisis deskriptif kuantitatif. Analisis inferensial dilakukan untuk menguji korelasi antarvariabel menggunakan uji korelasi dan regresi linier sederhana. Analisis secara deskriptif digunakan untuk menampilkan data berdasarkan besaran-besaran dalam statistik. Selain itu, data keterampilan proses berpikir matematis mahasiswa dikelompokkan pada distribusi yang mengacu pada predikat yang digunakan di program studi Pendidikan Matematika Universitas Muria Kudus.

\section{HASIL DAN PEMBAHASAN}

Berdasarkan tahapan penelitian, mahasiswa diberikan tes untuk mengukur hasil belajar mahasiswa aspek kognitif dan keterampilan proses berpikir matematisnya. Data yang diperoleh kemudian dianalisis untuk menguji hubungan antara keterampilan proses berpikir matematis mahasiswa dengan hasil belajar mahasiswa dan mendeskripsikan keterampilan proses berpikir matematis mahasiswa.

\section{Uji Hubungan Keterampilan Proses Berpikir Matematis Dengan Hasil Belajar Mahasiswa}

Pengujian untuk membuktikan hipotesis penelitian ini menggunakan uji korelasi antarvariabel dan regresi. Namun, terlebih dahulu perlu dilakukan pengujian normalitas dan homogenitas data pada variabel terikat yaitu data hasil belajar mahasiswa. Berdasarkan uji normalitas menggunakan Kolmogorof-Smirnov diperoleh bahwa nilai Asymp. Sig (2-tailed) data hasil belajar mahasiswa adalah 0,923 . Hal ini menunjukkan bahwa nilai tersebut melebihi taraf nyata 0,05 , sehingga data berasal dari populasi yang berdistribusi normal. Selanjutnya uji homogenitas data hasil belajar dianalisis melalui frequencies pada descriptive statistics di SPSS. Berdasarkan output SPSS diperoleh nilai kurtosis data sebesar 0,332 . Nilai kurtosis menunjukkan nilai negatif yang artinya data cenderung tumpul. Namun, nilai tersebut tidak jauh dari angka nol sehingga dapat disimpulkan bahwa data cenderung homogen.

Setelah memenuhi uji prasyarat, maka analisis korelasi dan regresi linier sederhana dapat dilakukan. Analisis tersebut digunakan untuk menguji hubungan antara keterampilan proses berpikir matematis mahasiswa dengan hasil belajar mahasiswa. Hipotesis yang digunakan untuk menguji hubungan antarvariabel penelitian adalah sebagai berikut.
$H_{0}: \rho=0$ (tidak terdapat hubungan yang signifikan antara keterampilan proses berpikir matematis (X) dengan hasil belajar mahasiswa (Y));
$H_{1}: \rho \neq 0$ (terdapat hubungan yang signifikan antara keterampilan proses berpikir matematis (X) dengan hasil belajar mahasiswa (Y)).

Kriteria yang digunakan untuk pengujian hipotesis tersebut yaitu tolak 
DOI: https://doi.org/10.24127/ajpm.v10i1.3361

$H_{0}$ apabila nilai sig. (2-tailed) $<0,05$.

SPSS ditampilkan pada Tabel 1.

Output analisis korelasi menggunakan

Tabel 1. Output SPSS uji korelasi

\begin{tabular}{|c|c|c|c|}
\hline & & $\begin{array}{l}\text { Keterampilan Proses } \\
\text { Berpikir Matematis }\end{array}$ & $\begin{array}{c}\text { Hasil Belajar } \\
\text { Mahasiswa }\end{array}$ \\
\hline \multirow{3}{*}{$\begin{array}{l}\text { Keterampilan } \\
\text { Proses Berpikir } \\
\text { Matematis }\end{array}$} & Pearson Correlation & 1 & .516 \\
\hline & Sig. (2-tailed) & & .006 \\
\hline & $\mathrm{N}$ & 27 & 27 \\
\hline \multirow{3}{*}{$\begin{array}{l}\text { Hasil Belajar } \\
\text { Mahasiswa }\end{array}$} & Pearson Correlation & .516 & 1 \\
\hline & Sig. (2-tailed) & .006 & \\
\hline & $\mathrm{N}$ & 27 & 27 \\
\hline
\end{tabular}

Nilai sig. (2-tailed) pada output analisis korelasi product moment yang dapat dilihat pada Tabel 1 yaitu adalah 0,006. Berdasarkan hasil tersebut maka terjadi penolakan $H_{0}$ karena nilai sig. $(2$-tailed $)<0,05$. Dalam hal ini maka terdapat hubungan yang signifikan antara keterampilan proses berpikir matematis dengan hasil belajar mahasiswa.

Pengujian berikutnya untuk menguji signifikansi hubungan maka perlu dilakukan uji regresi linier sederhana. Berdasarkan hasil uji regresi sederhana dihasilkan 40,690 sebagai konstanta a dan 0,570 sebagai arah regresi b. Hubungan dari variabel keterampilan proses berpikir matematis dengan hasil belajar mahasiswa digambarkan oleh persamaan regresi $\widehat{Y}=40,690+0,570 X$. Langkah berikutnya persamaan regresi yang diperoleh harus diuji untuk memenuhi hubungan linier. Hipotesis yang digunakan untuk menganalisis linieritas yaitu:

$H_{0}: b=0 \quad$ (X tidak mempunyai hubungan linier terhadap $\mathrm{Y})$;

$H_{1}: b \neq 0$ (X mempunyai hubungan linier terhadap Y).

Kriteria yang digunakan untuk pengujian hipotesis uji linieritas yaitu tolak $H_{0}$ apabila nilai sig. (2-tailed) < 0,05 . Output uji linieritas menggunakan SPSS ditampilkan pada Tabel 2.

Tabel 2. Output SPSS uji linieritas

\begin{tabular}{llccccc}
\hline Model & & Sum of Squares & df & Mean Square & F & Sig. \\
\hline 1 & Regression & 1626.622 & 1 & 1626.622 & 9.053 & $.006^{\text {a }}$ \\
& Residual & 4492.044 & 25 & 179.682 & & \\
& Total & 6118.667 & 26 & & & \\
\hline
\end{tabular}

Pada Tabel 2 tersaji nilai sig. pada output uji linieritas adalah 0,006. Hal ini menunjukkan bahwa nilai sig. $<0,05$ sehingga terjadi penolakan $H_{0}$. Oleh karena $H_{1}$ diterima, maka $\mathrm{X}$ mempunyai hubungan linier terhadap Y. Dalam hal ini antarvariabel penelitian telah mempunyai hubungan linier, sehingga variabel $\mathrm{X}$ berpengaruh positif terhadap Y. Hubungan yang positif antarvariabel dapat dilihat dari tanda positif pada koefisien regresi.

Setelah uji linieritas dilakukan, maka dapat dilanjutkan untuk 
DOI: https://doi.org/10.24127/ajpm.v10i1.3361

menentukan seberapa besar pengaruh variabel $X$ terhadap variabel $Y$. Hal ini dilakukan dengan melihat koefisien determinasi pada output uji regresi. Hasil output SPSS besar pengaruh $X$ terhadap $Y$ ditampilkan pada Tabel 3.

Tabel 3. Besar pengaruh $X$ terhadap $Y$

\begin{tabular}{crrrr}
\hline Model & R & R Square & Adjusted R Square & Std. Error of the Estimate \\
\hline 1 & $.516^{\text {a }}$ & .266 & .236 & 13.405 \\
\hline
\end{tabular}

Nilai koefisien determinasi dapat dibaca melalui $R$ square $\left(R^{2}\right)$ pada Tabel 3. Nilai koefisien determinasi mengindikasikan bahwa hasil belajar mahasiswa dipengaruhi oleh keterampilan proses berpikir matematis sebesar 26,6\% melalui hubungan linier. Selain itu sebesar $73,4 \%$ hasil belajar mahasiswa dipengaruhi oleh faktor lain selain keterampilan proses berpikir matematis. Hubungan linier antarvariabel sebesar $\hat{Y}=40,690+$ $0,570 X$ dapat menjelaskan variasi hasil belajar mahasiswa dengan keterampilan proses berpikir matematis yang dimiliki mahasiswa.

\section{Hasil Analisis Deskriptif Data} Keterampilan Proses Berpikir Matematis Mahasiswa

Analisis deskriptif data pada penelitian ini digunakan untuk menyajikan data terkait keterampilan proses berpikir matematis mahasiswa Program Studi Pendidikan Matematika yang berada di semester VI dan pada mata kuliah Analisis Kompleks. Datadata analisis deskriptif yang disajikan meliputi banyaknya mahasiswa, nilai tertinggi dan nilai terendah yang diperoleh mahasiswa, rata-rata, median, modus, varians, dan simpangan baku. Secara deskriptif semua data terkait keterampilan proses berpikir matematis mahasiswa dirangkum dapat dilihat pada Tabel 4.
Tabel 4. Deskripsi data keterampilan proses berpikir matematis

\begin{tabular}{clc}
\hline No & Statistik Deskriptif & Nilai \\
\hline 1 & Banyak Mahasiswa & 27 \\
2 & Nilai Tertinggi & 85 \\
3 & Nilai Terendah & 25 \\
4 & Rata-rata & 62,96 \\
5 & Median & 70 \\
6 & Modus & 70 \\
7 & Varians & 192,81 \\
8 & Simpangan Baku & 13,88 \\
\hline
\end{tabular}

Dari Tabel 4 terlihat bahwa nilai tertinggi mahasiswa sudah baik, tetapi nilai terendah yang dicapai mahasiswa masih sangat jauh dari nilai 100 . Ratarata keterampilan proses berpikir matematis mahasiswa tergolong kurang baik karena hanya mencapai nilai 62,96 . Nilai tengah dan nilai yang sering muncul pada data keterampilan proses berpikir matematis mahasiswa adalah 70. Secara keseluruhan keterampilan proses berpikir matematis mahasiswa perlu diperbaiki karena memiliki ratarata dan skor minimumnya masih tergolong rendah.

Analisis deskriptif data pada penelitian ini juga digunakan untuk menyajikan data keterampilan proses berpikir matematis mahasiswa untuk setiap indikator. Secara deskriptif data keterampilan proses berpikir matematis mahasiswa sesuai indikator keterampilan proses berpikir matematis disajikan pada Tabel 5. 
DOI: https://doi.org/10.24127/ajpm.v10i1.3361

Tabel 5. Deskripsi data keterampilan proses berpikir matematis

\begin{tabular}{clc}
\hline No & \multicolumn{1}{c}{ Indikator } & Persentase \\
\hline 1 & $\begin{array}{l}\text { Menentukan pola dan } \\
\text { menarik kesimpulan }\end{array}$ & $58,33 \%$ \\
2 & $\begin{array}{l}\text { Mengkomunikasikan } \\
\text { masalah ke dalam ide } \\
\text { matematik }\end{array}$ & $32,41 \%$ \\
3 & $\begin{array}{l}\text { Melakukan } \\
\text { perhitungan } \\
\text { matematika }\end{array}$ & $82,87 \%$ \\
\hline
\end{tabular}

Berdasarkan hasil yang disajikan pada Tabel 5, terlihat bahwa terdapat dua indikator keterampilan proses berpikir matematis mahasiswa yang belum dicapai dengan baik sehingga keterampilan proses berpikir matematis mahasiswa belum optimal karena hanya mencapai rata-rata $57,87 \%$. Selain dianalisis secara deskriptif, data keterampilan proses berpikir matematis mahasiswa dikonversikan pada distribusi yang mengacu pada predikat yang digunakan di program studi Pendidikan Matematika Universitas Muria Kudus. Hasil pengelompokannya ditampilkan dalam Tabel 6.

Tabel 6. Profil keterampilan proses berpikir matematis mahasiswa

\begin{tabular}{ccc}
\hline Nilai & Predikat & $\begin{array}{c}\text { Banyak } \\
\text { Mahasiswa }\end{array}$ \\
\hline $85 \leq$ nilai $\leq 100$ & A & 2 \\
$75 \leq$ nilai $<85$ & AB & 1 \\
$67 \leq$ nilai $<75$ & B & 13 \\
$61 \leq$ nilai $<67$ & BC & 1 \\
$55 \leq$ nilai $<61$ & C & 5 \\
$45 \leq$ nilai $<55$ & CD & 2 \\
$35 \leq$ nilai $<45$ & D & 2 \\
$0 \leq$ nilai $<35$ & E & 1 \\
\hline
\end{tabular}

Dari Tabel 6 terlihat bahwa sebagian besar keterampilan proses berpikir matematis mahasiswa hanya mencapai predikat B. Masih ada 5 mahasiswa yang memperoleh nilai kurang dari C. Berdasarkan Tabel 4 sebelumnya diperoleh bahwa rata-rata keterampilan proses berpikir matematis mahasiswa tergolong pada predikat BC.

Sesuai tahapan penelitian yang pertama dilakukan pengujian hipotesis yang meliputi analisis korelasi antarvariabel dan regresi. Namun, pengujian normalitas dan homogenitas data pada variabel terikat yaitu data hasil belajar mahasiswa perlu dilakukan. Hal ini dimaksudkan karena uji asumsi kenormalan dan homogenitas dilakukan pada galat dan galat berdampak pada variabel dependen, sehingga uji prasyarat ini hanya dilakukan pada variabel terikat (Sukestiyarno, 2012). Hasil uji prasyarat menunjukkan bahwa data berasal dari populasi yang berdistribusi normal dan homogen.

Setelah uji prasyarat dipenuhi, maka pengujian korelasi dapat dilakukan. Hasilnya menunjukkan bahwa terdapat hubungan yang signifikan antara keterampilan proses berpikir matematis dengan hasil belajar mahasiswa. Kekuatan hubungan antarvariabel ditunjukkan oleh nilai $r_{X Y}$ sebesar 0,516. Jika nilai $r_{X Y}$ yang dihasilkan masuk di antara rentang 0,400 dan 0,599 maka korelasi yang terjadi tergolong cukup kuat (Sugiyono, 2016). Dengan demikian disimpulkan bahwa terdapat hubungan positif yang cukup kuat antara keterampilan proses berpikir matematis dengan hasil belajar mahasiswa.

Hubungan antarvariabel keterampilan proses berpikir matematis dengan hasil belajar mahasiswa digambarkan oleh persamaan regresi $\hat{Y}=40,690+$ $0,570 X$. Kedua variabel penelitian mempunyai hubungan linier, sehingga variabel $\mathrm{X}$ berpengaruh positif terhadap Y. Hasil belajar mahasiswa dipengaruhi oleh keterampilan proses berpikir 
matematis sebesar $26,6 \%$ melalui hubungan linier. Selain itu sebesar $73,4 \%$ hasil belajar mahasiswa dipengaruhi oleh faktor lain selain keterampilan proses berpikir matematis. Hal ini sejalan dengan hasil penelitianpenelitian lain yang menguji faktor yang mempengaruhi hasil belajar. Faktor yang mempengaruhi hasil belajar matematika mahasiswa diataranya yaitu kecemasan matematika (Novikasari, 2016). Namun, hasil belajar mahasiswa tidak dipengaruhi oleh gaya belajar mahasiswa (Wahyuni, 2017; Wardhani et al., 2016). Pada penelitian ini hasil belajar mahasiswa dipengaruhi faktor lain seperti kemandirian belajar, kecemasan matematika, kemampuan matematis, dan lain-lain. Namun karena dalam penelitian ini hanya berfokus pada faktor keterampilan proses berpikir matematis, maka besar pengaruh faktor lain yang mempengaruhi hasil belajar tidak terdeteksi secara pasti.

Persamaan regresi $\hat{Y}=40,690+$ $0,570 X$ ini mengisyaratkan bahwa jika ada peningkatan keterampilan proses berpikir matematis mahasiswa maka akan diikuti oleh kenaikan hasil belajar mahasiswa sebanyak 0,570 unit pada konstanta 40,690. Jika semakin tinggi keterampilan proses berpikir matematis mahasiswa, maka akan semakin tinggi hasil belajar mahasiswa.

Keterampilan proses berpikir matematis mahasiswa dinilai berdasarkan indikator (1) menentukan pola dan menarik kesimpulan, (2) mengkomunikasikan masalah ke dalam ide matematika, dan (3) melakukan perhitungan matematika (Aminah \& Firmasari, 2017). Berdasarkan hasil penelitian, keterampilan proses berpikir matematis mahasiswa perlu dikembangkan. Rata-rata dan skor minimum yang dicapai tergolong rendah. Rendahnya keterampilan proses berpikir matematis mahasiswa salah satunya disebabkan karena mahasiswa kurang memperhatikan proses penyelesaian masalahnya. Mahasiswa hanya fokus pada hasil akhir jawabannya. Hal ini senada dengan hasil penelitian yaitu mayoritas peserta didik dalam menyelesaikan masalah kurang memperhatikan langkah-langkah penyelesaiannya dan hanya mementingkan hasil akhirnya saja (Khamidah \& Suherman, 2016).

Menurut analisis profil mahasiswa berdasarkan indikator keterampilan proses berpikir matematis, mahasiswa mengalami kesulitan dalam mengkomunikasikan masalah ke dalam ide matematika. Kendala peserta didik dalam mengkomunikasikan ide matematika yaitu pada saat menafsirkan permasalahan menjadi model matematika dan peserta didik terbiasa hanya menyelesaikan masalah secara mekanik (Rahayu et al., 2018; Wijayanto et al., 2018). Mahasiswa masih kesulitan menyelesaikan permasalahan yang menuntut untuk berpikir lebih kompleks.

Dalam pembelajaran dosen atau pendidik seyogyanya dapat menciptakan suasana belajar yang penuh dengan tantangan namun menyenangkan. Melalui pembelajaran yang menarik bagi mahasiswa keterampilan berpikir matematika peserta didik akan berkembang. Selain itu kemampuan mahasiswa dalam mengeksplorasi konsep-konsep matematika juga penting untuk perkembangan keterampilan proses berpikir matematis mahasiswa (Dewi, 2017). Oleh karena terdapat hubungan yang signifikan antara keterampilan proses berpikir matematis dengan hasil belajar mahasiswa, maka dengan berkembangnya keterampilan berpikir matematis mahasiswa nantinya akan 
berdampak pada hasil belajar yang semakin baik pula.

Di dalam hasil belajar matematika diperlukan suatu proses untuk berpikir secara matematis. Proses berpikir ini dialami sesorang ketika mendapat stimulus sehingga menghasilkan respon yang berupa kemampuan untuk menghubungkan sesuatu dengan sesuatu yang lainnya untuk menyelesaikan/ menjawab suatu permasalahan (Rahayu et al., 2019). Proses berpikir yang dikembangkan dalam matematika menggunakan kaidah-kaidah penalaran (Sapa'at, 2020). Dengan demikian keterampilan proses berpikir matematis sangat relevan dengan proses penyelesaian masalah di dalam kehidupan sehari-hari, sehingga mahasiswa perlu memiliki keterampilan proses berpikir matematis yang mumpuni.

Hasil belajar mahasiswa dalam penelitian ini diukur menggunakan penilaian tertulis. Hal ini sejalan dengan pendapat Dachi, bahwa salah satu bentuk penilaian hasil belajar untuk peserta didik yaitu dengan tes tertulis (paper and pencil test) (Dachi, 2017). Penilaian hasil belajar dilakukan setelah penerapan pembelajaran.

Dalam penelitian ini ditemukan bahwa terdapat hubungan antara keterampilan proses berpikir matematis mahasiswa dengan hasil belajar mahasiswa dan belum optimalnya keterampilan proses berpikir matematis mahasiswa terutama pada indikator mengkomunikasikan masalah ke dalam ide matematik. Hasil penelitian ini memberikan hasil yang belum pernah dilakukan penelitian sebelumnya mengenai kajian hubungan antara keterampilan proses berpikir matematis mahasiswa dan besar pengaruhnya terhadap hasil belajar mahasiswa. Namun, dalam penelitian ini belum mengukur aspek lain yang dapat mempengaruhi hasil belajar mahasiswa, seperti kemandirian belajar, kecemasan matematika, kemampuan matematis, dan lain-lain. Hasil penelitian ini dapat berkontribusi sebagai acuan untuk melakukan penelitian lebih lanjut dengan tujuan untuk meningkatkan keterampilan proses berpikir matematis peserta didik. Jika keterampilan proses berpikir matematis peserta didik meningkat, maka diharapkan agar hasil belajar peserta didik akan meningkat pula.

\section{KESIMPULAN DAN SARAN}

Berdasarkan hasil penelitian diperoleh simpulan sebagai berikut: (1) terdapat hubungan antara keterampilan proses berpikir matematis mahasiswa dengan hasil belajar mahasiswa. dan (2) sebagian besar keterampilan proses berpikir matematis mahasiswa hanya mencapai predikat B yaitu sebesar $48,15 \%$ mahasiswa, rata-rata keterampilan proses berpikir matematis mahasiswa adalah 62,96, secara klasikal tergolong pada predikat $\mathrm{BC}$, dan berdasarkan indikator, keterampilan proses berpikir matematis mahasiswa belum optimal karena hanya mencapai rata-rata $57,87 \%$.

Rekomendasi atas keterbatasan penelitian ini yaitu pada penelitian selanjutnya dapat mengukur aspek lain yang dapat mempengaruhi hasil belajar mahasiswa, seperti kemandirian belajar, kecemasan matematika, kemampuan matematis, dan lain-lain. Selain itu, dalam proses pembelajaran mahasiswa dapat dilibatkan secara aktif agar keterampilan proses berpikir matematisnya berkembang semakin baik sehingga hasil belajar mahasiswa juga semakin baik. 


\section{DAFTAR PUSTAKA}

Aminah, N., \& Firmasari, S. (2017). Keterampilan Proses Berpikir Matematika Mahasiswa Ditinjau dari Performance Assessment. Jurnal Euclid, 3(2), 588-603.

Andriani, Ikhsan, M., \& Ansari, B. I. (2016). Peningkatan Kemampuan Pemahaman dan Motivasi Siswa SMP melalui Model Missouri Mathematics Project (MMP) dengan Menggunakan Game Matematika Online. Jurnal Didaktik Matematika, 3(1), 55-63.

Dachi, S. W. (2017). Upaya Meningkatkan Hasil Belajar Matematika Melalui Strategi Belajar Small Group Work pada Mahasiswa Jurusan Matematika Fakultas Keguruan dan Ilmu Pendidikan Universitas Muhammadiyah Sumatera Utara. Jurnal EduTech, 3(1), 109-116.

Dewi, I. A. S. (2017). Analisis Keterampilan Proses Pemecahan Masalah Matematika Siswa pada Model Pembelajaran Inquiry. Prosiding Seminar Nasional Integrasi Matematika Dan Nilai Islami UIN Malang, 469-475.

Khamidah, K., \& Suherman. (2016). Proses Berpikir Matematis Siswa dalam Menyelesaikan Masalah Matematika Ditinjau dari Tipe Kepribadian Keirsey. Al-Jabar: Jurnal Pendidikan Matematika, $7(2)$, 231-248. https://doi.org/https://doi.org/10.24 042/ajpm.v7i2.38

Novikasari, I. (2016). Hubungan Antara Prestasi Belajar Dan Tingkat Kecemasan Matematika Pada Mahasiswa Calon Guru SD/MI. Aksioma: Jurnal Program Studi Pendidikan Matematika, 5(2), 120-127. https://doi.org/http://dx.doi.org/10. 24127/ajpm.v5i2.671

Rahayu, R., Ulya, H., Kartono, \& Isnarto. (2019). Asesmen Kolaboratif Pada Pembelajaran Etnomatematika Untuk Mengukur Kemampuan Berpikir Matematis dan Disposisi. Pena Persada.

Rahayu, R., Ulya, H., Kartono, Isnarto, \& Kurniasih, N. (2018). Collaborative Assessment Using QR-Code on Ethnomathematics Learning for Pre-Service Teacher. International Journal of Engineering \& Technology, 7(2.13), 413-417.

Salmi, H., Vainikainen, M. P., \& Thuneberg, H. (2015). Mathematical Thinking Skills, Self-Concept and Learning Outcomes of 12-Year-Olds Visiting a Mathematics Science Centre Exhibition in Latvia and Sweden. Journal of Science Communication, 14(04), 1-19.

Sapa'at, A. (2020). Pengembangan Keterampilan Berpikir Matematis Melalui Pembelajaran Matematika. Jurnal Pendidikan Dompet Dhuafa, 10(1).

Sugiyono. (2016). Statistika Untuk Penelitian. Alfabeta.

Sukestiyarno, Y. L. (2012). Statistika Dasar. Universitas Negeri Semarang.

Sumarmo, U. (2013). Kumpulan Makalah, Disposisi dan Berfikir Kritis Matematika Serta Pembelajarannya. Jurusan Pendidikan Matematika FMIPAUPI.

Wahyuni, A. (2017). Korelasi Antara Gaya Belajar Terhadap Hasil Belajar Mahasiswa Pada Mata Kuliah Kalkulus Dasar. Jurnal Karya Pendidikan Matematika, 4(1). https://doi.org/https://doi.org/10.26 
DOI: https://doi.org/10.24127/ajpm.v10i1.3361

714/jkpm.4.1.2017.\%25p

Wardhani, I. S., Hanik, U., \& Wulandari, R. (2016). Pengaruh Gaya Belajar Terhadap Hasil Belajar Matematika Mahasiswa Universitas Trunojoyo. Jurnal Pendidikan Dan Pembelajaran Matematika, 2(1), 42-54. https://doi.org/http://dx.doi.org/10. 29100/jp2m.v2i1.215

Widyaningtyas, R. (2010). Peranan Guru dalam Melakukan Penilaian Ketrampilan Proses. Educare: Jurnal Pendidikan Dan Budaya, 1(1).

Wijayanto, A. D., Fajriah, S. N., \& Anita, I. W. (2018). Analisis Kemampuan Komunikasi Matematis Siswa SMP Pada Materi Segitiga dan Segiempat. Journal Cendekia: Jurnal Pendidikan Matematika, 2(1), 97-104. https://doi.org/https://doi.org/10.31 004/cendekia.v2i1.36

Yulianto, A., Fatchan, A., \& Astina, I. K. (2017). Penerapan Model Pembelajaran Project Based Learning Berbasis Lesson Study Untuk Meningkatkan Keaktifan Belajar Siswa. Jurnal Pendidikan: Teori, Penelitian, Dan Pengembangan, 2(3), 448-453. https://doi.org/http://dx.doi.org/10. 17977/jptpp.v2i3.8729 